\title{
FORMULASI EKSTRAK KLOROFORM DAUN BELIMBING WULUH DALAM BENTUK SEDIAAN GEL dan UJI AKTIVITAS ANTIBAKTERI TERHADAP Staphylococcus epidermidis
}

\author{
Verawaty ${ }^{1}$, Nova Tri Rahmadhani ${ }^{2}$, Irene Puspa Dewi ${ }^{3}$ \\ ${ }^{1,2,3}$ Akademi Farmasi Prayoga Padang \\ Email Korespondensi : verawaty77@gmail.com
}

\begin{abstract}
ABSTRAK
Pengobatan herbal sangat dibutuhkan untuk mengobati berbagai penyakit, salah satunya adalah daun belimbing wuluh (Averrhoa bilimbi L.). Penelitian ini bertujuan untuk memformulasi ekstrak kloroform daun belimbing wuluh (Averrhoa bilimbi L.) menjadi sediaan gel yang baik, efektif, dan aman untuk digunakan serta mengetahui aktivitas antibakteri pada gel ekstrak kloroform daun belimbing wuluh (Averrhoa bilimbi L.) terhadap Staphylococcus epidermidis dengan metode sumuran. Jenis penelitian ini adalah eksperimen laboratorium. Hasil gel yang didapatkan berupa gel berbentuk kental, berwarna hijau gelap, bau khas ekstrak daun belimbing wuluh, homogen, $\mathrm{pH}$ kulit yang baik, daya cuci yang baik dan tidak mengiritasi kulit. Penelitian ini menggunakan media Nutrient Agar sebagai media biakan bakteri Staphylococcus epidermidis. Hasil penelitian ini menunjukkan bahwa sediaan gel ekstrak kloroform daun belimbing wuluh pada formula I (10\%), formula II (20\%), dan formula III (30\%) mampu menghambat pertumbuhan bakteri Staphylococcus epidermidis. Pada formula III (30\%) gel ekstrak daun belimbing wuluh mempunyai zona daya hambat terluas dibandingkan dengan formula sediaan lainnya. Uji statistik menggunakan uji One Way ANOVA menunjukkan adanya perbedaan yang bermakna dari rata-rata diameter zona hambat antara semua konsentrasi sediaan gel ekstrak kloroform daun belimbing wuluh yang signifikan dengan $(\alpha<0,05)$.
\end{abstract}

Kata kunci: Gel, Daun Belimbing Wuluh (Averrhoa bilimbi L.), Staphylococcus epidermidis. 


\title{
FORMULATION CHLOROFORM EXTRACT OF BELIMBING WULUH LEAVES IN THE FORM OF GEL PREPARATION AND ANTIBACTERIAL ACTIVITY TEST AGAINST Staphylococus epidermidid
}

\begin{abstract}
Herbal treatments are needed to treat various diseases, one of which is the leaves of Belimbing Wuluh (Averrhoa bilimbi L.). The aim of this study was to formulate chloroform extract of Belimbing Wuluh's leaf (Averrhoa bilimbi L.) into gel preparations that were good, effective, and safe to use and to determine the antibacterial activity of chloroform extract of Belimbing Wuluh (Averrhoa bilimbi L.) leaf extract to Staphylococcus epidermidis by well method. The results showed that form of gel is a thick, dark green, the distinctive smell of Wuluh starfruit leaf extract, homogeneous, good skin $\mathrm{pH}$, good washing and does not irritate the skin. This study uses Nutrient Agar media as a culture medium for Staphylococcus epidermidis bacteria. The results indicate that the chloroform extract gel leaves of belimbing wuluh leaves in formula I $(10 \%)$, formula II (20\%), and formula III (30\%) were able to inhibit the growth of Staphylococcus epidermidis bacteria. In formula III (30\%) gel extract of belimbing wuluh leaves has the widest zone of inhibition compared to other dosage formulas.
\end{abstract}

Keywords : Gel, Belimbing Wuluh leaves (Averrhoa bilimbi L.), Staphylococcus epidermidis.

\section{PENDAHULUAN}

Belimbing Wuluh (Averrhoa bilimbi L) telah digunakan secara tradisional untuk berbagai macam penyakit. Hampir seluruh bagian pada Belimbing Wuluh dapat digunakan sebagai pengobatan dan terbukti megandung berbagai macam metabolit sekunder. Salah satunya adalah Daun Belimbing Wuluh. Kandungan metabolit sekunder yang terdapat pada Daun Belimbing Wuluh adalah flavonoid ( luteolin dan apigenin), tanin, sulfur, dan beberapa jenis asam lainnya (Fitri, 2008).

Flavonoid dan tanin memiliki salah satu fungsi yang kerjanya sebagai antibakteri. Pada penelitian Zakaria et al., (2007) menunjukkan bahwa ekstrak air daun belimbing wuluh pada konsentrasi $100 \quad \mathrm{mg} \quad \mathrm{mL}^{-1}$ dapat menghambat pertumbuhan bakteri Gram positif dan Gram negatif. Ekstrak kloroform daun belimbing wuluh (Averrhoa bilimbi L.) pada konsentrasi $100 \mathrm{mg} \mathrm{mL}^{-1}$ mempunyai aktivitas antibakteri terhadap bakteri Gram positif dan Gram negatif (Zakaria; et al, 2007). Salah satu jenis bakteri Gram positif yang dapat dihambat dengan ekstrak kloroform Daun belimbing wuluh adalah Staphylococcus epidermidis. Bakteri ini banyak terdapat di kulit dan mengakibatkan infeksi pada kulit. Bentuk sediaan farmasi yang paling mudah digunakan di kulit adalah bentuk sediaan Gel. Gel mudah digunakan, jernih, bentuknya lebih menarik, memiliki rasa dingin ketika 
dioleskan pada permukaan kulit, mudah tercuci sehingga penggunaanya lebih disenangi dan kemampuan penyebarannya pada kulit lebih baik (Fitri, 2008).

Penelitian ini merupakan penelitian lanjutan dari penelitian Zakaria pada tahun 2007 dengan menformulasi ekstrak kloroform Daun Belimbing Wuluh menjadi sediaan Gel dan kemudian sedian Gel diuji aktivitas antibakterinya terhadap bakteri Staphylococcus epidermidis.

\section{METODE PENELITIAN MATERIAL}

Bahan yang digunakan daun belimbing wuluh dan ekstrak kloroform daun belimbing wuluh dengan konsentrasi $10 \%$, 20\%, dan 30\%; kloroform (KGaA), HPMC (Methocel), Clindamycin Gel (kontrol positif), Aquadest steril (kontrol negatif), dan Nutrient Agar (KGaA), propilen glikol (Propylene glycol), $\mathrm{NaCl}$ fisiologis 0,9\% (Ecosol $\mathrm{NaCl}$ ), alkohol 70\%, alkohol $96 \%$.

\section{RANCANGAN PENELITIAN}

Penelitian ini merupakan penelitian eksperimental yang dilakukan di Laboratorium Akademi Farmasi Prayoga Padang. Sampel yang digunakan dalam penelitian adalah daun belimbing wuluh (Averrhoa bilimbim L.) yang diambil dari Kampung Duri Kota Padang. Tahapan-tahapan yang dilakukan pada penelitian ini adalah

1. Penyiapan simplisia daun belimbing wuluh.

Daun belimbing wuluh dibersihkan dari kotoran yang melekat kemudian daun belimbing wuluh dirajang lalu dikeringkan pada ruangan yang tidak terkena sinar matahari langsung kemudian setelah kering dihaluskan dengan menggunakan blender (Verawaty, 2016).

2. Pembuatan ekstrak kloroform daun belimbing wuluh (Averrhoa bilimbi L.)

Daun belimbing wuluh yang telah halus kemudian dimaserasi dengan menggunakan pelarut kloroform (1 : 10)(Sukandar, E Y, 2014)

3. Pembuatan sediaan gel ekstrak klorofom daun belimbing wuluh (Averrhoa bilimbim L.)

Tabel 1. Formula Gel Eksrak Kloroform Daun Belimbing Wuluh

\begin{tabular}{|c|c|c|c|}
\hline \multirow{2}{*}{ Nama Bahan } & \multicolumn{3}{|c|}{ Formula } \\
\cline { 2 - 4 } & I & II & III \\
\hline $\begin{array}{c}\text { Ekstrak Kloroform Daun } \\
\text { Belimbing Wuluh }\end{array}$ & $10 \%$ & $20 \%$ & $30 \%$ \\
\hline HPMC & $1 \%$ & $1 \%$ & $1 \%$ \\
\hline Propilen Glikol & $10 \%$ & $10 \%$ & $10 \%$ \\
\hline Aquadest & Ad $100 \%$ & Ad $100 \%$ & Ad $100 \%$ \\
\hline
\end{tabular}

4. Evaluasi sediaan gel ekstrak kloroform daun belimbing wuluh
(Averrhoa bilimbim L.) (Ikhsanudin dan S Mardhiyah, 2017) 
Evaluasi dilakukan setelah disimpan selama 1 minggu dan evaluasi meliputi

a. Organoleptis

Uji organoleptis meliputi warna dan bau

b. Homogenitas

Pemeriksaan dilakukan dengan menggoreskan sejumlah tertentu sediaan pada kaca objek. Susunan sediaan harus homogen dan tidak terlihat butir-butir kasar.

c. pemeriksaan $\mathrm{pH}$

pemeriksaan $\mathrm{pH}$ dengan menggunakan $\mathrm{pH}$ meter

d. uji iritasi kulit

Uji iritasi kulit merupakan uji kepekaan yang dilakukan dengan cara mengoleskan sediaan uji langsung pada kulit dengan maksud mengetahui apakah sediaan uji dapat menimbulkan iritasi kulit atau tidak.

5. Uji aktivitas antibakteri dengan mengukur zona bening gel ekstrak kloroform daun belimbing wuluh terhadap bakteri Staphylococcus epidermidis (Sukandar, E Y, 2014; Verawaty, 2016)

Pada uji aktivitas antibakteri ini menggunakan media Nutrien Agar (NA) dengan metoda sumuran.

\section{HASIL DAN PEMBAHASAN}

Penyiapan simplisia dan pembuatan ekstrak kloroform daun belimbing wuluh

Daun belimbing wuluh (Averrhoa bilimbi L.) dicuci dengan air mengalir untuk membuang kotoran-kotoran yang ada pada daun kemudian daun dirajang untuk mempermudah pengeringan. Proses pengeringan bertujuan untuk mendapatkan simplisia yang awet, tidak rusak dan dapat digunakan atau disimpan dalam jangka waktu relatif lama. Proses pengeringan menggunakan metoda dikering anginkan pada suhu kamar dan terhindar dari cahaya matahari langsung. Setelah kering, daun belimbing wuluh dibuat menjadi simplisia. Tujuannya adalah untuk memperluas permukaan sampel sehingga proses ekstraksi lebih optimal (Verawaty, 2016). Simplisia daun belimbing wuluh kemudian dimaserasi dengan menggunakan pelarut kloroform, setelah didapatkan hasil maserat kemudian hasil maserat dipekatkan dengan menggunakan Rotary Evaporator.

Pembuatan sediaan gel ekstrak klorofom daun belimbing wuluh (Averrhoa bilimbim L.)

Basis gel yang digunakan dalam formulasi yaitu HPMC. Pemilihan HPMC sebagai basis gel karena HPMC dapat mengembang dalam air dan menghasilkan viskositas yang sesuai dengan syarat viskositas gel. Sebagai humektan pada formulasi gel ini digunakan propilenglikol yang bertujuan untuk menjaga kelembaban kulit, meningkatkan daya sebar sediaan, serta melindungi kemungkinan terjadinya kekeringan pada gel (Herslambang, 2015)

Evaluasi sediaan gel ekstrak klorofom daun belimbing wuluh (Averrhoa bilimbim L.)

Hasil evaluasi yang dilakukan pada gel meliputi: organoleptis, homogenitas, $\mathrm{pH}$, daya tercuci, serta uji iritasi kulit. 
Pada uji organoleptis, homogenitas terlihat tidak ada perbedaan antara bentuk, bau, homogenitas pada sediaan gel walaupun dalam konsentrasi yang berbeda. Untuk warna yang dihasilkan pada gel mengalami perubahan, semakin besar konsentrasi pada formula, maka warna pada sediaan gel semakin pekat hal ini disebabkan oleh semakin banyaknya ekstrak daun belimbing wuluh yang ditambahkan pada sediaan gel tersebut. Untuk $\mathrm{pH}$ memiliki perbedaan di tiap-tiap

Tabel 2. Hasil Evaluasi Gel konsentrasi yaitu, semakin besar konsentrasi sediaan gel maka $\mathrm{pH}$ yang diperoleh juga semakin besar. $\mathrm{pH}$ yang didapatkan pada formula $1(10 \%)$ yaitu 5,02 , pada formula $2(20 \%)$ yaitu, 5,09 , dan pada formula 3 (30\%) yaitu, 5,20. Hasil pengukuran menunjukkan bahwa $\mathrm{pH}$ sediaan gel yang diperoleh memenuhi standar $\mathrm{pH}$ kulit yaitu berada dalam interval $\mathrm{pH}$ 4,5-6,5(Genaro, 1990). Pada uji iritasi pada kulit maka sediaan gel yang dibuat tidak mengiritasi kulit (Tabel 2).

\begin{tabular}{|c|c|c|c|}
\hline \multirow{2}{*}{ Evaluasi gel } & \multicolumn{3}{|c|}{ Formula } \\
\cline { 2 - 4 } Bentuk & $\mathbf{1 0 \%}$ & $\mathbf{2 0 \%}$ & $\mathbf{3 0 \%}$ \\
\hline Warna & Hijau bening & Hental & Kental \\
\hline Bau & Khas ekstrak & Khas ekstrak & Khas ekstrak \\
\hline Homogenitas & Homogen & Homogen & Homogen \\
\hline pH & 5,02 & 5,09 & 5,20 \\
\hline $\begin{array}{c}\text { Uji iritasi } \\
\text { kulit }\end{array}$ & Tidak mengiritasi & Tidak mengiritasi & Tidak mengiritasi \\
\hline
\end{tabular}

Uji aktivitas antibakteri gel ekstrak kloroform daun belimbing wuluh terhadap bakteri Staphylococcus epidermidis

Pada uji aktivitas antibakteri menggunakan bakteri Staphylococcus epidermidis karena bakteri ini merupakan flora normal pada kulit manusia yang pada umumnya dapat menimbulkan penyakit pembengkakan (abses) seperti jerawat (Yulianingsih, 2012).

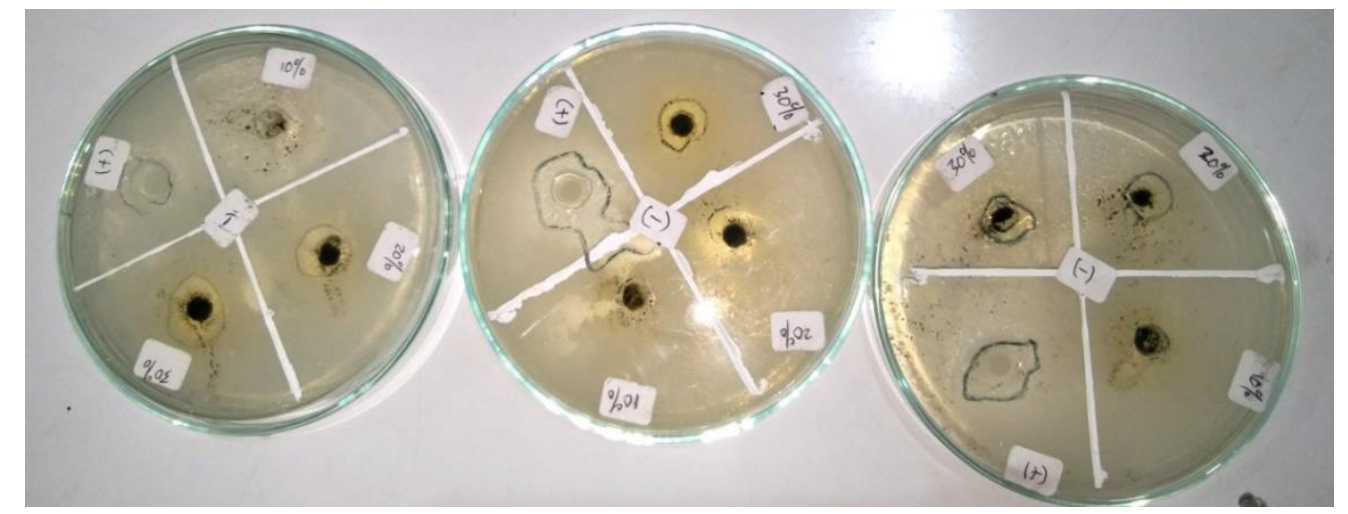


Gambar 1. Aktivitas Bakteri Staphylococcus epidermidis terhadap Sediaan Gel Tabel 3. Diameter Zona Hambat Bakteri Staphylococcus epidermidis

\begin{tabular}{|c|c|c|c|c|c|c|}
\hline \multirow{3}{*}{$\begin{array}{c}\text { Cawan } \\
\text { Petri }\end{array}$} & \multicolumn{5}{|c|}{ Zona Daya Hambat (mm) } \\
\cline { 2 - 4 } & \multicolumn{3}{|c|}{ Sediaan Gel } & \multirow{2}{*}{ Ekstrak } & \multicolumn{2}{c|}{ Kontrol } \\
\cline { 2 - 5 } \cline { 6 - 7 } & $\mathrm{F} 1$ & $\mathrm{~F} 2$ & $\mathrm{~F} 3$ & & + & - \\
\hline 1 & 7 & 9,9 & 10,425 & 4,75 & 16,35 & 0 \\
\hline 2 & 9,8 & 14,95 & 14,55 & 6,875 & 21,7 & 0 \\
\hline 3 & 7,05 & 12,35 & 16,275 & 6,5 & 13,1 & 0 \\
\hline Rata-rata & $7,95 \pm 1,6$ & $12,4 \pm 2,5$ & $13,75 \pm 3,0$ & $6,04 \pm 1,1$ & $17,05 \pm 4,3$ & $0 \pm 0$ \\
\hline
\end{tabular}

Hal ini menunjukkan bahwa sediaan gel ekstrak daun belimbing wuluh, formula 3 (30\%) gel ekstrak daun belimbing wuluh mempunyai diameter terluas dibandingkan dengan formula sediaan lainnya. Berdasarkan hasil penelitian menunjukkan bahwa semakin tinggi konsentrasi formula sediaan maka semakin luas daya hambat bakterinya. Zona hambat pada kontrol negatif adalah 0, hal ini menunjukkan bahwa proses penelitian berjalan dengan baik dan steril. Zona hambat pada kontrol positif sebesar 17,05 mm. Bila dibandingkan dengan kontrol positif maka kekuatan gel konsentrasi 30\% sebesar $80 \%$ dari kekuatan kontrol positif. Data yang diperoleh dianalisa menggunakan program komputer SPSS (Statistical Product and Service Solutio) 17.0 for windows. Hasil analisa menunjukkan bahwa terdapat perbedaan rata-rata diameter zona hambat pada konsentrasi kelompok adalah signifikan dengan $(\alpha<0,05)$ yang berarti antara konsentrasi $10 \%, 20 \%$, dan $30 \%$ terdapat perbedaan yang bermakna, tidak ada perbedaan yang bermakna antara kontrol positif dengan formula yang berkonsentrasi 30\% dari sediaan gel ekstrak daun belimbing wuluh terhadap pertumbuhan bakteri Staphylococcus epidermidis.

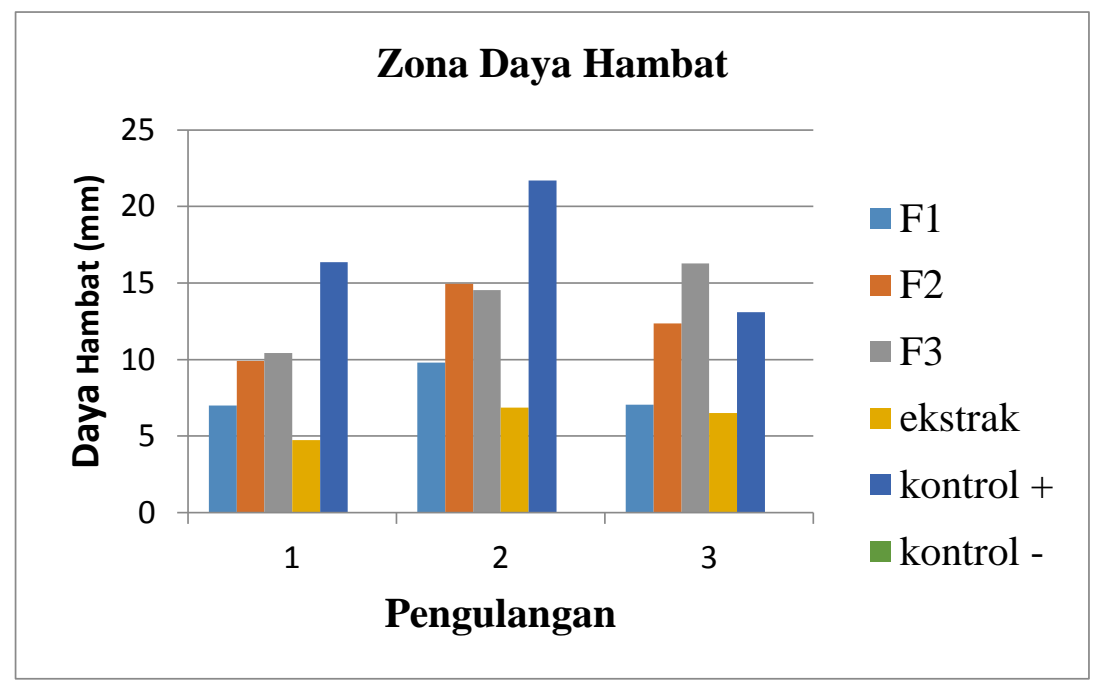




\section{Gambar 2. Diagram Batang Hasil Data Zona Daya Hambat}

\section{KESIMPULAN}

Dari penelitian yang dilakukan, dapat disimpulkan bahwa:

1. Ekstrak kloroform daun belimbing wuluh dapat diformula menjadi sediaan gel berdasarkan hasil evaluasi gel yang dapat memenuhi syarat sebagai sediaan gel.

2. Sediaan gel dari ekstrak daun belimbing wuluh dengan konsentrasi $30 \%$ memiliki zona daya hambat terbesar dan merupakan konsentrasi yang efektif dalam menghambat pertumbuhan bakteri Staphylococcus epidermidis.

\section{UCAPAN TERIMA KASIH}

Pada kesempatan ini, peneliti ingin mengucapkan terima kasih kepada Yayasan Prayoga Padang yang telah memberikan dukungan baik moril maupun material kepada peneliti.

\section{DAFTAR PUSTAKA}

Genaro, R. A. 1990. Remington's Pharmaceutical Science. 18th ed. Macle Printing Company, EastonPennsilva, USA.

Fitri, W. E. (2008). Formulasi Gel dari Ekstrak Etanol Buah Belimbing Wuluh (Averrhoa bilimbi Linn) Sebagai Anti Jerawat.Skripsi. Fakultas Farmasi Universitas Andalas, Padang

Herslambang, D. (2015). Aktivitas Sediaan Gel Kuersetin Terhadap Staphylococcus Epidermidis. Galenika Journal of Pharmacy, 1(1), 59-64.

Ikhsanudin dan S Mardhiyah -, \& 2017. (2017). Formulasi dan Uji Antijerawat Gel Ekstrak Etanol $70 \%$ Buah Belimbing Wuluh (Averrhoa bilimbi Linn.) terhadap Bakteri Propionibacterium acnes. Jurnal MEDULA, 5(1), 416-426.
Sukandar, E Y, dkk. (2014). Uji Aktivitas Antimikroba Ekstrak Etanol Buah Belimbing Wuluh ( Averrhoa bilimbi L .) terhadap Propionibacterium acnes, Staphylococcus epidermidis, MRSA dan MRCNS. Acta Pharmaceutica Indonesia, XXXIX(3), 51-56.

Verawaty. (2016). Pengaruh Konsentrasi Ekstrak Etanol Kulit Dan Biji Petai (Parkia speciosa Hassk) terhadap Bakteri Escherichia coli. Jurnal Akademi Farmasi Prayoga, 1(1), 8-12.

Yulianingsih. (2012). Antibakteri Ekstrak Etanol Daun Belimbing Wuluh (Averrhoa bilimbi. L.) Terhadap Staphylococcus aureus dan Staphylococcus epidermidis, Skripsi, Fakultas Farmasi Universitas Muhammadiyah Surakarta.

Zakaria; et al. (2007). In vitro Antibacterial Activity of Averrhoa bilimbi L. Leaves and Fruits Exracts. International Journal of Tropical Medicine, 2(3), 96-100. 